Utah State University

DigitalCommons@USU

$\mathrm{Da}$

Bee Lab

4-1-2001

\title{
Australian Lasioglossum + Homalictus Form a Monophyletic Group: Resolving the "Australian Enigma"
}

Bryan N. Danforth

Cornell University

Shuqing Ji

Cornell University

Follow this and additional works at: https://digitalcommons.usu.edu/bee_lab_da

Part of the Entomology Commons

\section{Recommended Citation}

Danforth, Bryan N. and Ji, Shuqing, "Australian Lasioglossum + Homalictus Form a Monophyletic Group: Resolving the "Australian Enigma"'" (2001). Da. Paper 455.

https://digitalcommons.usu.edu/bee_lab_da/455

This Article is brought to you for free and open access by the Bee Lab at DigitalCommons@USU. It has been accepted for inclusion in Da by an authorized administrator of DigitalCommons@USU. For more information, please contact digitalcommons@usu.edu.

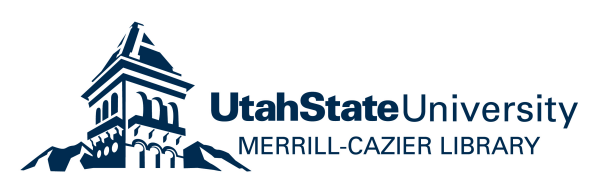


C: \hgp \aussie.v4

systematic Biology (in press)

RH: DANFORTH \& JI -- RESOLVING THE "AUSTRALIAN ENIGMA"

Australian Lasioglossum + Homalictus form a monophyletic group: resolving the "Australian enigma"

Bryori N. Danforth ${ }^{1} \&$ Shuqing $\mathrm{Ji}$

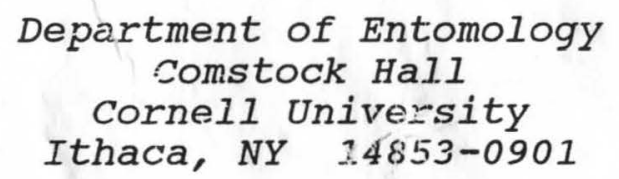

${ }^{1}$ Corresponding author

Proofs to:

Bryan N. Danforth

Department of Entomology

Comstock Hall

Cornell University

Ithaca, NY 14853-0901

phone: 607-255-3563/FAX: 607-255-0939

internet: bnd1ecornell.edu 
Danforth \& Ji

Abstract -- The bee genus Lasioglossum includes over 1000 species of bees distributed on all continents except Antarctica. Lasioglossum is a major component of the bee fauna in the Holarctic, Ethiopian, and oriental regions, and is an important group for investigating the evolution of social behavior in bees. Given its cosmopolitan distribution, the historical biogeography of the genus is of considerable interest. We reconstructed phylogenetic relationships among the subgenera and species within Lasioglossum s.s. using DNA sequence data from a slowly evolving nuclear gene, EF-1 $\alpha$. The entire data set includes over 1604 aligned nucleotide sites (including three exons plus two introns) for 89 species (17 outgroups plus 72 ingroups). Parsimony and maximum likelihood analyses provide strong evidence that the primarily Indoaustralian subgenera (Homalictus, Chilalictus, Parasphecodes) form a monophyletic group. Bootstrap support for the Australian clade ranged from 73\% to 77\% (depending on the method of analysis). Monophyly of the Australian Lasioglossum suggests that a single colonization event (via Southeast Asia and New Guinea) gave rise to a lineage of over 350 native Indoaustralian bees. We discuss the implications of Australian monophyly for resolving the "Australian enigma" -- similarity in social behavior among the Australian halictine bees relative to Holarctic groups.

[Key words: biogeography, phylogeny, maximum likelihood, elongation factor $-1 \alpha$, social evolution] 
The Australian bee fauna is remarkable in many ways. Over half of the species of Australian bees belong to one family (Colletidae), which is commonly considered to be the most plesiomorphic of bees (Alexander \& Michener, 1995). In addition, major families in other parts of the world are absent in Australia (Andrenidae and Melittidae), and Australia is surprisingly depauperate in parasitic bees (Wcislo, 1988). While the endemic Australian Colletidae (Euryglossinae) and stenotritidae, and the predominantly Australian Paracolletini and Hylaeinae may represent groups that became isolated on Australia during the breakup of Gondwana in the Mesozoic, many other groups of bees have clearly colonized Australia from the north via Southeast Asia and New Guinea (Michener, 1979a). Numerous independent colonization events have occurred within the bee family Halictidae because several distantly related genera now occupy parts of Australia: Nomioides Schenck (Nomioidinae, $1 \mathrm{sp.,}$ Yeates \& Exley, 1986), Lipotriches Gerstaecker (=Nomia Latreille; Nomiinae, approximately 70 spp., Cardale, 1993 and Michener 2000), Sphecodes Latreille (Halictinae, 2 sp., Cardale, 1993), Pachyhalictus Cockerell (Halictinae, 2 spp., Walker, 1993, 1996), Lasioglossum Curtis (Halictinae, many species, Michener, 1965; Walker, 1995), and Homalictus Cockerell (Halictinae, many species; Walker, 1986, 1997). By far the largest groups of Indoaustralian halictid bees are in the related genera Lasioglossum and Homalictus, which together account for nearly 350 species of Australian halictine bees.

The genus Lasioglossum includes over 1000 species worldwide with numerous subgenera and species groups recognized. The subgeneric groupings within Lasioglossum are treated by some authors as separate genera (see Krombein, et al., 1979; Moure \& Hurd, 1987) because they comprise such large and diverse taxa. others treat Lasioglossum as a genus consisting of many subgenera 
(Ebmer, 1987; Michener, 2000). For the purposes of this paper, we will refer to the genus Lasioglossum and its numerous subgenera (e.g., the Lasioglossum subgenus Chilalictus is referred to below as L. (Chilalictus), the Lasioglossum subgenus Parasphecodes as L. (Paraphecodes), and so on for all subgenera listed in Table 1).

Michener (2000) divided the subgenera of Lasioglossum into two groups: the Hemihalictus series, which includes all subgenera with a weakened 1st $r-m$ cross vein in females, and the Lasioglossum series, which includes all subgenera with a completely sclerotized 1st $r-m$ cross vein (Table 1 ). Six of the eight subgenera within the Lasioglossum series consist predominantly or exclusively of endemic Australian species: Australictus, Callalictus, Chilalictus, Glossalictus, Parasphecodes, and Pseudochilalictus (Table 1).

While Homalictus (plus the cleptoparasitic derivative, Echthralictus Perkins \& Cheesman, found in Samoa [Perkins \& Cheesman, 1928; Michener, 1965, 1978a]) has not recently been considered a subgenus of Lasioglossum (Michener, 2000), both morphological characters (Lasioglossum sensu lato and Homalictus share weakened $2 \mathrm{r}-\mathrm{m}$ and $2 \mathrm{~m}-\mathrm{cu}$ cross veins in females (see Fig. 1 in Danforth, 1999)) and molecular data presented below indicate that Homalictus arises from within Lasioglossum. We have therefore chosen to refer to Homalictus as a subgenus of Lasioglossum throughout this paper. While Homalictus has its center of diversity in Australia, many species occur in New Guinea (Pauly, 1986; Michener, 1980a) and the group occurs as far north as Sri Lanka and southeast Asia and thence southward and eastward to Indonesia (Pauly, 1980), the Philippines (Cockerell, 1919 ; Michener, 1980b), and the islands of Fiji (Michener, 1979b) and Samoa, however all the available evidence suggests that Homalictus has its origins in Australia (Michener, 1979a). Members of Indoaustralian Lasioglossum and Homalictus are 
distinct both behaviorally and, to a lesser extent, morphologically, from their Holarctic relatives in the genus Lasioglossum. First, like most Australian bees, they primarily visit plants in the family Myrtaceae (such as Melaleuca and Eucalyptus; Walker, 1986 and Michener, 1965) for pollen and nectar. Other important sources of pollen and nectar include plants in the families Mimosaceae (such as Acacia), Proteaceae (such as Banksia), and Papilionaceae (Berhhardt \& Walker, 1984, 1985; Bernhardt, 1987; Walker, 1986), and, to a lesser extent, Amaranthaceae, Asteraceae, Lamiaceae, Dilleniaceae, Frankeniaceae, Goodeniaceae, Haemodoraceae, Haloragaceae, Myoporaceae, Portulacaceae, Rutaceae, Solanaceae, Sterculiaceae, and Xanthorrhoeaceae (T. Houston, pers. comm.). Australian halictines are generally considered narrowly polylectic, in that most species restrict pollen foraging to Myrtaceae but will visit a diverse array of genera depending on locality. Nevertheless, a number of species are clearly oligolectic. Lasioglossum (Chilalictus) megacephalum is restricted to Goodeniaceae, L. (Chilalictus) frankenia is oligolectic on Frankenia (Frankeniaceae), and numerous species of Chilalictus are oligolectic on Wahlenbergia (Campanulaceae) (Walker, 1995). Only two subgenera of Holarctic Lasioglossum, Hemihalictus (Daly, 1961) and Sphecodogastra (McGinley, 2000), are known to be oligolectic.

More importantly, the Australian Lasioglossum and Homalictus have a unique array of behavioral attributes that distinguishes them from Lasioglossum in other parts of the world (Michener, 1960; Knerer \& Schwarz, 1976, 1978). All species studied to date exhibit either solitary or communal nesting behavior (Michener, 1960, 1974), such that multiple females share a nest but do not cooperate in cell provisioning or show reproductive division of labor. Michener (1960) conducted a broad survey of species in Homalictus, Chilalictus and Parasphecodes by dissecting females 
collected on flowers. For virtually all species examined, $100 \%$ of females are fertilized. Such results provide strong, though indirect, evidence that these species are not eusocial. More detailed studies involving nest excavations and dissections of foraging and resident females have been conducted on additional species, including L. (Chilalictus) lanarium (Knerer \& Schwarz, 1978), L. (Chilalictus) cognatum (as L. [Chilalictus] inclinans, Knerer \& Schwarz, 1978), L. (Chilalictus) platycephalum (as L. [Chilalictus] mesembryanthemiellum, Knerer \& Schwarz, 1978; McConnell-Garner \& Kukuk, 1997), L. (Chilalictus) leai (as Halictus leai, Cardale \& Turner, 1966), and L. (Chilalictus) hemichalceum (Rayment, 1955; Houston, 1970; Kukuk, 1992; Kukuk \& Schwarz, 1987, 1988; Kukuk \& Crozier, 1990; Kukuk \& Sage, 1994; Ward \& Kukuk, 1998). In all cases, nests contained multiple, reproductively active females, and in some cases there was evidence of overlap in generations. Nests may be huge in some species, such as Homalictus urbanus, which has up to 160 females per nest (T. Houston obs., cited in Walker, 1986).

Among the more remarkable aspects of communal Australian Lasioglossum is that they defend their nests by plugging the nest entrance with the metasoma (Rayment, 1935; Michener, 1960; P. Kukuk pers. comm.; BND pers. obs.) while showing low levels of aggression towards conspecifics (Kukuk \& Crozier, 1990; Kukuk, 1992 ; Kukuk \& Sage, 1994). Molecular genetic studies indicate that nestmates in communal Chilalictus are unrelated (Kukuk \& Sage, 1994) as one would expect for communal (as opposed to eusocial) species. Communal nesting is rare in the Holarctic groups of Lasioglossum. Species in the nominate subgenus, Lasioglossum s.s., have been observed by numerous authors to be solitary, while most species in the Hemihalictus series are primitively eusocial (e.g., numerous species of Dialictus and Evylaeus; see Michener [1990], Packer [1993], Yanega [1997], and Wcislo [1997] for reviews). 
At least one species of Australian Lasioglossum ( $L$. [Chilalictus] hemichalceum) shows discrete male dimorphism while male positive head allometry is widespread in the subgenus Chilalictus (Walker, 1995). Large-headed males in $L$. (Chilalictus) hemichalceum have been interpreted as guards (Houston, 1970; Kukuk \& Schwarz, 1988).

Nest architecture in the Australian Lasioglossum and Homalictus is also distinct from their Holarctic relatives. All Australian Lasioglossum and Homalictus construct cells either in series (e.g., in Homalictus and some Chilalictus) or in clusters (some Chilalictus) (Knerer \& Schwarz, 1976). Holarctic Lasioglossum typically construct sessile cells off of a central nest tunnel, as in L. (Evylaeus) marginatum, L. (Evylaeus) malachurum, and many species of $L$. (Dialictus), although some species (L. [Evylaeus] duplex) construct cells in clusters (Michener, 1974).

This unique suite of social attributes present in the Australian Lasioglossum and Homalictus was referred to by Knerer \& Schwarz (1976) as the "Australian enigma." They presumed that the social behavior of the Australian halictines was convergently evolved, perhaps in response to heavy ant predation on groundnesting bees, or in response to mutillid wasp attack (Rayment citations, in Michener, 1960). The classification of Australian halictine bees would not have suggested a common ancestral origin for Australian Lasioglossum and Homalictus, since Homalictus was considered a distinct genus, and even the Australian subgenera of Lasioglossum are not obviously monophyletic based on morphology (Michener, 1965). In addition, there is substantial morphological diversity among the Australian subgenera of Lasioglossum. Within Chilalictus alone there are small, metallic greenish species that superficially resemble North American Dialictus (in fact they were classified as such [using the synonymous name chloralictus] prior to Michener's 1965 study), small black species similar to 
Northern Hemisphere Evylaeus, and large species with metasomal hair bands and imbricate mesosomal sculpturing that resemble Northern Hemisphere Lasioglossum s.s.

We sought to test the hypothesis that the Australian subgenera of Lasioglossum plus Homalictus form a monophyletic group by analyzing a large nucleotide data set for a diverse array of species within Lasioglossum and Homalictus plus outgroups. If the Indoaustralian Lasioglossum + Homalictus form a monophyletic group, we would conclude that the unique social attributes of the Australian halictine bees are derived from a common ancestor which also had those traits, rather than through convergent evolution in social behavior. Likewise, monophyly would suggest a single colonization of Australia in the distant past, rather than multiple, recent colonizations.

We chose a nuclear, protein-coding gene, elongation factor$1 \alpha(\mathrm{EF}-1 \alpha)$, for this study. EF-1 encodes an enzyme involved in the GTP-dependent binding of charged tRNAs to the acceptor site of the ribosome during translation (Maroni, 1993). Previous cladistic analyses of $\mathrm{EF}-1 \alpha$ sequence data have found that this gene provides useful phylogenetic information across a wide range of divergence times (Friedlander et al., 1992, 1994). Within insects, $\mathrm{EF}-1 \alpha$ has been shown to recover higher-level relationships in the moth subfamily Heliothinae (Cho et al., 1995), the moth superfamily Noctuoidea (Mitchell et al., 1997), and the bee genus Halictus (Danforth et al., 1999).

\section{MATERIALS AND METHODS}

Bees for this study were collected by the first author or generously provided by colleagues (see Acknowledgements). Specimens used for sequencing were primarily preserved in 95\% EtoH but recently collected pinned specimens (less than five years old) and frozen specimens were also used. Outgroup and 
Danforth \& Ji

ingroup taxa included in this study, locality data, specimen voucher numbers, and GenBank accession numbers are listed in Table 2 .

DNA extractions followed standard protocols detailed in Danforth (1999). Two sets of PCR products were used to generate the data set. Initially, primers were designed based on a comparison of published Drosophila (Hovemann et al., 1988), Apis (Walldorf \& Hovemann, 1990), and moth (Cho et al., 1995) sequences. Primers that initially amplified at least some halictid species included For1-deg, For3 and Cho10 (all primer sequences are listed in Danforth et. al, 1999). Based on initial comparisons of the F1 and F2 copies of EF-1 $\alpha$ in halictid bees, we developed a new, F2-specific, reverse primer (F2-Rev1). For the downstream ( $3^{\prime}$ ) end of EF-1 $\alpha$ we used primers For3/Cho10. These primers amplify both EF-1 $\alpha$ copies, however the presence of a roughly 200-250 bp intron in the F2 copy allows these PCR products to be separated on low-melting point agarose gels. Only the F2 copy was included in the present analysis.

PCR amplifications were carried out following standard protocols (Palumbi, 1996), with the following cycle conditions: $94^{\circ} \mathrm{C}$, 1 min denaturation; $50-56^{\circ} \mathrm{C}, 1 \mathrm{~min}$ annealing; $72^{\circ} \mathrm{C}, 1 \mathrm{~min}$ to $1 \mathrm{~min} 20 \mathrm{sec}$ extension. Prior to sequencing PCR products were either gel-purified in low-melting point agarose gels (FMC, Rockland, Maine) overnight at $4^{\circ} \mathrm{C}$, or directly using the Promega (Madison, Wisconsin) Wizard PCR Preps DNA Purification kit.

For manual sequencing we used ${ }^{33} \mathrm{P}$-labelled dideoxy chain termination reactions (Thermo Sequenase radiolabelled terminator cycle sequencing kit; Amersham Inc, cleveland, ohio) and standard 8\% polyacrylamide gel electrophoresis, as indicated in the Amersham product manual.

Automated sequencing of PCR products was performed on an ABI 377 automated sequencer available through the Cornell Automated Sequencing Facility. Overall we sequenced EF-1 $\alpha$ F2 in 89 species, 
three of which were represented by more than one locality (giving a total of 92 OTUs). The region analyzed below corresponds with

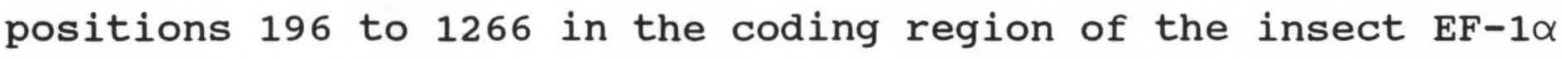
gene (Danforth \& Ji, 1998), meaning our data set spans $77 \%$ of the 1386 bp coding region (Walldorf \& Hovemann, 1990). As in the previous report (Danforth \& Ji, 1998), we found two introns within the region analyzed (at locations $753 / 754$ and 1029/1030).

\section{Taxon sampling}

While it was not possible to obtain representatives of all Lasioglossum subgenera, this study includes species from all the major subgenera. Of the eighteen widely recognized subgeneric groupings (five of which are monotypic), we included at least one member of nine of these groups and have sampled extensively within the three major North American and European subgenera Dialictus, Evylaeus, and Lasioglossum s.s., as well as two major Australian subgenera, Chilalictus (Walker, 1995) and Parasphecodes. For the subgenus Evylaeus we included representatives of several species groups (as defined by Ebmer, 1995, 1997). Among the acarinate Evylaeus (as defined in Ebmer, 1997) we included representatives of the morio, brevicorne, lucidulum/tarsatum, politum, and puncticolle species groups. Among the carinate Evylaeus (as defined in Ebmer, 1995) we included representatives of the calceatum, fulvicorne/fratellum, interruptum, laticeps, malachurum, marginatum, and pauxillum species groups. The only large species groups that are missing from our data set are the marginellum, punctatissimum, and trincinctum groups. This paper focusses on the relationships among the Lasioglossum series of subgenera. A later paper (Danforth, in prep.) will focus on the subgeneric and speciesgroup relationships within the Hemihalictus series.

Parsimony analysis 
Phylogenetic analyses of nucleotide and amino acid sequences were performed using a beta test version of PAUP* (PAUP v. 4.0b2, Swofford, 1999). For equal weights parsimony analyses we used heuristic search with TBR branch swapping, random addition sequence for taxa, and fifty replicates per search. Bootstrap analysis (Felsenstein, 1985) was used to evaluate branch support on parsimony trees. Bootstrap values were calculated based on 100 replicates with ten random sequence additions per replicate and maxtrees set at 200 .

Because our data set includes non-coding intron sequences, we inferred insertion/deletion mutations in the two included introns. However, it was possible to align the intron regions with little difficulty and gaps were generally short (from 1 to 4 bp in length). When analyzing the introns we employed gap coding methods developed by Hervé Sauquet and described in Danforth et al. (1999). This method of gap coding assigns individual indel mutations (of whatever length) a weight equal to a single nucleotide substitution while at the same time retaining information on sequence variation within indels. We report below only the analyses based on this gap coding method, but other methods (coding gaps as missing data and as a fifth state) gave similar results. Alignments for both the original and the recoded data sets are available from the corresponding author.

\section{Maximum likelihood analysis}

For the maximum likelihood (ML) analyses we initially used the equal weights parsimony trees obtained based on the gap-coded matrix to estimate the log likelihood of each tree under 20 distinct models of sequence evolution (Sullivan \& Swofford, 1997; Frati et al., 1997; Huelsenbeck \& Crandall, 1997). The four basic models were Jukes-Cantor (JC), Kimura two-parameter (K2P), Hasegawa-Kishino-Yano (HKY) and the General Time Reversible (GTR) model (Swofford, et al., 1996). Within each model we had five 
methods of accounting for rate heterogeneity: no rate heterogeneity, gamma distributed rates (G), proportion of invariant sites (I), gamma + invariant sites ( $I+G)$, and sitespecific rates (SSR; where each codon position plus introns were assigned a different rate). Using site-specific rates was appropriate in this case, because rate catagories could be identified a priori and because there were clear differences in rates among sites (see below).

Once likelihoods were calculated based on equal weights parsimony trees, we then performed branch swapping using appropriate ML models with a series of increasingly exhaustive branch swapping algorithms, in the following order: NNI, SPR(1), SPR(2), TBR(1), and TBR(2). Before each round of branch swapping the ML parameters were re-estimated based on the trees currently in memory and applied to the next round of branch swapping. The parameter estimates resulting from this search algorithm are discussed below. In all cases our branch swapping algorithms converged on the same tree irrespective of the model selected (see below).

For the ML analyses we excluded the following taxa in order to reduce search time: L. (Parasphecodes) olgae (Ctsp153), L. (Lasioglossum) albocinctum, L. (Lasioglossum) leucozonium (Lale133), L. (Dialictus) imitatum, L. (Evylaeus) albipes (Eval104), L. (Evylaeus) comagenense, L. (Evylaeus) duplex, and L. (Sphecodogastra) oenotherae. These sequences were all very similar to other sequences in the data set, either because they represented additional specimens of the same species, or because they are closely related to another species in the data set.

\section{RESULTS}

\section{Alignment}

The 92 sequences were aligned using MegAlign in the 
Lasergene software package (DNASTAR Inc., Madison, Wisconsin). Apis mellifera (Walldorf \& Hovemann, 1990) was included as a reference to determine the reading frame of the sequences. The region analyzed consists of two introns and three exons, as judged by comparison with the Apis coding sequence. Intron/exon junctions were universally AG/GT or AG/GA motifs.

Together the three exons represent 1,074 bp of aligned sequence with no insertion/deletion (indel) mutations observed. Intron 1 (positions 559-844) includes 286 aligned nucleotide sites (with 11 gap coded characters), and intron 2 (positions 1121-1364) includes 244 total aligned nucleotides (with 11 gap coded characters). The entire data set includes 1604 aligned nucleotide sites plus 22 numerical characters representing gapcoded variation. For the purposes of the analysis below we deleted two regions. First, we deleted an A/T rich insertion (positions 597-659) in intron 1 that was impossible to align and present in only 21 species (this proved to be a synapomorphic insertion, see below). Second, a 9 bp region (positions 15421550) in exon 3 that was subject to compression on manual sequencing gels was deleted.

\section{Base composition}

The overall base composition and the base composition broken down by character partition is shown in Table 3 . Overall the base composition was only slightly A/T-biased (55\%). The A/T bias was most significant in introns, where $A$ and $T$ accounted for $65 \%$ of the nucleotides. There was no significant heterogeneity among taxa in the proportion of bases based on a chi-square test (Table 3).

Phylogenetic analysis

In all analyses presented below we included 17 outgroup taxa in the following halictine genera: Halictus Latreille, 
Agapostemon Guérin-Méneville, Pseudagapostemon Schrottky, Sphecodes Latreille and Mexalictus Eickwort, Augochlora Smith, Augochloropsis Cockerell, Megalopta Smith, and Neocorynura Schrottky (Table 2).

Equal weights parsimony analyses. -- Fig. 1 shows a strict consensus tree of the 336 equally parsimonious trees obtained based on an analysis of the entire data set (exonstintrons). Two major clades within Lasioglossum are evident, supporting Michener's division of the genus into the Hemihalictus and Lasioglossum series (Table 1; Michener, 2000). Among the subgenera of the Lasioglossum series there were three major clades. First, the basal branch includes species of Lasioglossum s.s. from Europe and N. America, including L.(L.) laevigatum, L.(L.) lativentre, L.(L.) sexnotatum (European species) plus L.(L.) pavonotum, L.(L.) fuscipenne, L. $\left(L_{\bullet}\right)$ desertum, $L_{\bullet}\left(L_{\bullet}\right)$ coriaceum, L.(L.) sisymbrii, and L.(L.) titusi (all North American species). Most of the species included in this group have a weakly sculptured propodeal dorsal area that is long in relation to the metanotum. Second, the branch including $L_{\text {. }}\left(L_{\bullet}\right)$ leucozonium and $L .(L$.$) zonulum (both of which occur in North$ America and Europe) and the exclusively Palaearctic species, L. (L.) discum, L.(L.) callizonium, L.(L.) majus, and $L_{\text {. }}$ (L.) albocinctum. These species (plus $L_{\bullet}\left(L_{\bullet}\right)$ aegyptiellum and $L_{\bullet}\left(L_{\bullet}\right)$ subopacum) are referred to as the Lasioglossum leucozonium species group (see Packer, 2000). The leucozonium group is united by at least four morphological characters (Packer, 2000), including (1) a patch of erect setae on the male S6 (Packer's character 63), (2) a flattened apical gonostylus (Packer's character 76), (3) ventral retrorse lobes of the gonostylus lacking (Packer's character 78), and (4) relatively short and coarsely sculptured propodeal dorsal area in females. Sister to the leucozonium group is a lineage of Indoaustralian subgenera 
and species, including Parasphecodes, Homalictus, Chilalictus, and Australian species tentatively placed in a new subgenus ( $L$. [Subgen. Nov. N.] NDA(1)-A; K. Walker, pers. comm.). This group will be referred to below as the "Australian clade" (Fig. 1). Within the Hemihalictus series relationships among species are reasonably well resolved. Our $\mathrm{EF}-1 \alpha$ data set recovers a monophyletic subgenus Dialictus, places the subgenera Hemihalictus and Sudila in the "acarinate Evylaeus", and recovers monophyly of the Evylaeus calceatum group. Relationships within the Hemihalictus series imply that Evylaeus is paraphyletic with respect to several other subgenera included in this study (including Dialictus, Hemihalictus, Sudila, Sphecodogastra, and Paralictus). Based on the equal weights parsimony analysis neither the carinate nor the acarinate Evylaeus are monophyletic (Fig. 1).

Clades that are well supported by bootstrap values include Lasioglossum s.1. (97\%), the Lasioglossum series of subgenera (95\%), the Hemihalictus series of subgenera (100\%), the Lasioglossum leucozonium group (100\%), the leucozonium group + Australian clade (100\%), and the Australian clade (76\%) (Fig. 2). Interestingly, the $\mathrm{A} / \mathrm{T}$ rich insertion in intron 1 (positions 597659) proved to be a unique and unreversed synapomorphy of the leucozonium group plus the Australian clade, providing strong support for the monophyly of this group. Bootstrap support for the Australian clade varied from $73 \%$ to $77 \%$, depending on how gaps were treated in the parsimony analysis. Six characters support Australian monophyly and all are third position transitions.

The EF-1 $\alpha$ data provide strong support for Australian monophyly, and for the inclusion of Homalictus within Lasioglossum (see above). Relationships within the Hemihalictus series are well-resolved, and many higher-level groupings are clearly recovered by the $\mathrm{EF}-1 \alpha$ data, including monophyly of 
Dialictus, close relationship between Dialictus and the acarinate Evylaeus, and clear resolution within the carinate Evylaeus.

Inclusion of introns in the parsimony analysis is crucial to reconstructing relationships within Lasioglossum. While exons account for roughly twice the number of nucleotide sites sequenced, they account for only half of the parsimony informative sites (Table 4). Virtually all of the variation in exons $(86.4 \%)$ is in third position silent sites. As a result, the total number of parsimony informative amino acid changes was very small (Table 4).

Maximum likelihood analyses. -- We applied ML to our data for two reasons. First, there is substantial rate heterogeneity among sites. For coding sequences alone (exons) there are large differences among first, second, and third positions (with third positions evolving an order of magnitude faster than second positions). With the inclusion of non-coding introns there is an additional source of rate heterogeneity in that the introns evolve considerably faster than exons overall. Second, there is clear evidence of transition/transversion bias. Depending on the model of sequence evolution selected, transitions occur at a rate 3.67 to 4.12 times that of transversions, indicating that character state transformations within positions are not all equally probable.

As expected, the log likelihoods increased with increasingly complex models (Fig. 3). Allowing for variable transition/transversion ratios and accounting for rate heterogeneity among sites improved the likelihood scores considerably, however including empirical base frequencies (HKY) as opposed to equal base frequencies (K2P) did not improve the likelihood score as judged by the likelihood ratio test ( -2 in $\lambda$ $=-9.42, \mathrm{df}=3, \mathrm{~ns}$; Huelsenbeck \& Crandall, 1997). We chose to use the K2P model with site-specific rates because this was the 
simplest model that substantially improved the likelihood scores, and because search times under this model were shorter on the Power Mac G3 computer used for the ML analysis.

Branch swapping led to only slight increases in -Ln likelihood (from 15370.82 to 15361.75), indicating that the parsimony trees come very close to the tree topologies estimated under ML. In an analysis of the entire data set (exons and introns) we obtained one tree (-Ln likelihood $=15361.75$; Fig. 4). We also performed branch swapping under more complex models (e.g., HKY+SSR and GTR+SSR). In either case we obtained the same final tree topology as obtained with the simpler model (K2P+SSR). Estimates of the relative rate of substitution indicated that third positions evolve at roughly the same rate as introns, and both introns and third positions evolve roughly an order of magnitude faster than either first or second positions: introns, $1.64 ; \mathrm{nt1}, 0.17$; nt2, 0.06; nt3, 1.93 (based on the K2P+SSR model) .

The tree topology obtained using likelihood (Fig. 4) recovers many of the same higher nodes as the consensus of equally parsimonious trees (Fig. 1) and the 50\% bootstrap consensus tree (Fig. 2). Based on ML we recovered monophyletic Hemihalictus and Lasioglossum series, a monophyletic leucozonium group, a monophyletic Australian clade, and a sister group relationship between the leucozonium group and the Australian clade.

\section{DISCUSSION}

\section{Phylogenetic results}

While we were unable to include representatives of all the Australian subgenera, it is likely that the Australian subgenera that were not included (Callalictus, Pseudochilalictus, and Australictus) are closely related to those that were included in 
our analysis. Species of Australictus and Callalictus are similar morphologically to species of Parasphecodes. The relationship of Pseudochilalictus (a monotypic subgenus) to the other subgenera is not clear, but Pseudochilalictus may be closely related to Parasphecodes (possibly rendering Parasphecodes paraphyletic; K. Walker, pers. comm.)

The results presented above provide strong and unambiguous support for monophyly of Homalictus plus the Australian Lasioglossum irrespective of the data partitions analyzed, the methods used for coding gaps, or the methods of analysis (parsimony vs. likelihood). While this hypothesis is novel, it is not incompatible with any morphological characters.

\section{Biogeographic implications}

The sister group relationship implied by these data between the Lasioglossum leucozonium group and the Australian clade makes sense biogeographically. The subgenus Lasioglossum is widespread across the Palaearctic from western Europe to Japan and southward to southeast Asia. The leucozonium group is also widespread across the Palearctic region. The genus Lasioglossum (like Halictus, a closely related genus) is primarily a northern Hemisphere group. The Australian clade represents the only major radiation of Lasioglossum in the southern Hemisphere.

The presence of species of Homalictus outside of Australia is likely due to dispersal from Australia, rather than the reverse, as suggested by Michener (1979a), since the majority of species are Australian endemics.

The results presented here for Australian halictine bees parallel the results for bird higher level relationships as determined by DNA-DNA hybridization studies (Sibley \& Ahlquist, 1985, 1990; Sibley, Ahlquist, \& Monroe, 1988). The major lineage of passerine birds of the world (the oscines, suborder Passeres) is composed of two large, monophyletic, sister clades: the 
Parvorder Corvida and the Parvorder Passerida. These two lineages are estimated to have diverged in the Eocene or oligocene, according to molecular clock estimates from DNA-DNA hybridization (Sibley \& Ahlquist, 1990). The three major superfamilies within the Corvida include the Menuroidea (31 spp.), the Meliphagoidea (276 spp.) and the Corvoidea (794 spp.). Relationships implied by the DNA hybridization studies place the Meliphagoidea and Corvoidea as sister groups (Sibley, Ahlquist \& Monroe, 1988). Within the Parvorder Passerida there are three recognized superfamilies: Muscicapoidea (610 spp.), Sylvioidea (1195 spp.), and Passeroidea (1651 spp.), and the Sylvioidea and Passeroidea are sister groups. When one considers the zoogeographic distributions of these groups, it is clear that virtually all of the families within the Parvorder Corvida are endemic to Australia or share a common ancestor that was originally AustroPapuan. Two of the corvid superfamilies are exclusively Australian (Menuroidea and Meliphagoidea), and the majority of families within the Corvoidea are Austro-Papuan endemics. Derived members of the Parvorder Corvida have dispersed from Australia to other parts of the world, including Eurasia, N. America, and S. America. Groups that have dispersed from Australia or that have been derived from Australian ancestors include the Families Irenidae, Laniidae, Vireonidae, and three subfamilies within the family Corvidae (Corvinae, Aegithininae, and Malaconotinae).

While there are representatives of the Parvorder Passerida in Australia, these are recent colonists from groups with origins in Eurasia and Africa (Sibley \& Ahlquist, 1990). Because of the distinction between the two Parvorders, Sibley \& Ahlquist distinguish between the "old endemics" (including Australian members of the Parvorder Corvida) and the "new endemics" (including the Australian members of the Parvorder Passerida). Of the 700 species of Austro-Papuan passerines, 400 (57\%) are "old endemics." The recognition of Australian endemism in the Corvida 
resolved many problems in bird phylogeny because convergent evolution among members of the two Parvorders had obscured the true phylogenetic affinities in many cases.

our results for halictine bees parallel those of Sibley and Ahlquist for birds. A major radiation within Australia has given rise to an endemic fauna (400 species in the passerine birds and over 350 species of halictine bees) that shows convergent features with relatives from other parts of the world. As with Australian passerines, halictine bees that originated in Australia have given rise to descendants now present in neighboring regions, including Sri Lanka, southeast Asia, New Guinea, the Philippines (Homalictus), and Samoa (Echthralictus). That the Australian Lasioglossum + Homalictus form a monophyletic group helps resolve many questions in halictid bee social evolution and biogeography. Other major Australian radiations include the marsupial mammals (Archer, 1981) and the plant family Myrtaceae (Beadle, 1981).

Evidence of Australian monophyly among Lasioglossum subgenera also helps resolve the "Australian enigma" posed by Knerer \& Schwarz (1976). Similarity among the Australian Lasioglossum in flower associations, nest architecture, and sociality (with most Australian Lasioglossum being communal rather than eusocial) is likely due to common ancestry rather than convergent evolution. Ecological factors such as mutillid parasitism and ant predation may have favored communal associations among nestmates in the early Australian colonists. 


\section{ACKNOWLEDGEMENTS}

We are grateful to the following collaborators for providing specimens for this and future studies of halictid relationships: John Ascher, Manfred Ayasse, Connal D. Eardley, Michael Engel, Terry Griswold, Penelope F. Kukuk, Pat Lincoln, Yasuo Maeta, Ryouichi Miyanaga, Robert Minckley, John L. Neff, Beth Norden, Alain Pauly, Robert Paxton, Tai Roulston, Jerome G. Rozen, Jr., Michael Schwarz, Roy R. Snelling, William T. Wcislo, and Douglas Yanega. We are particularly grateful to stephan Reyes, Laurence Packer, Cecile Plateaux-Quénu, Kenneth Walker and Andreas W. Ebmer for providing identifications and crucial taxa, and for their interest in this work. The following people commented on early drafts of this paper: John Ascher, Karl Magnacca, and Charles Michener, and two reviewers provided numerous suggestions which substantially improved the paper. This project was supported by a National Science Foundation Research Grant in Systematic Biology (DEB-9508647) with travel funds provided by the Cornell International Agriculture Program. 


\section{Literature cited}

ALEXANDER, B.A. and C.D. MICHENER. 1995. Phylogenetic studies of the families of short-tongued bees (Hymenoptera: Apoidea). Univ. Kansas Science Bull. 55:377-424.

ARCHER, M. 1981. A review of the origins and radiations of Australian mammals. Pages 1435-1488 in Ecological Biogeography of Australia (A. Keast, ed.). W. Junk Publishers: The Hague, Boston, London.

BEADLE, N.C.W. 1981. Origins of the Australian angiosperm flora. Pages 407-426 in Ecological Biogeography of Australia (A. Keast, ed.). W. Junk Publishers: The Hague, Boston, London.

BERNHARDT, P. 1987. A comparison of the diversity, density, and foraging behavior of bees and wasps on Australian Acacia. Ann. Missouri Bot. Gard. 74:42-50.

BERNHARDT, P. and K. WALKER. 1984. Bee foraging on three sympatric species of Australian Acacia. Inter. J. Entom. 26: $322-330$.

BERNHARDT, P. and K. WALKER. 1985. Insect foraging on Acacia retinodes var. retinodes in Victoria, Australia. Int $\mathrm{J}$. Entomol. 27:97-101.

CARDALE, J.C. 1993. Hymenoptera: Apoidea. Zoological Catalogue of Australia (ed. by W.W.K. Houston and G.V. Maynard), pp. 167235. AGPS Vol. 10, Canberra.

CARDALE, J.C. and J.W. TURNER. 1966. Nest structure and biology of Halictus leai Cockerell (Hymenoptera: Halictidae). Proc. 
R. Soc. Queensland $77(10): 93-97$.

CHO, S., S. MITCHELL, J.C. REGIER, C. MITTER, R.W. POOLE, T.P. FRIEDLANDER, and S. ZHAO. 1995. A highly conserved nuclear gene for low-level phylogenetics: elongation factor $1-\alpha$ recovers morphology-based tree for heliothine moths. Mol. Biol. Evol. 12:650-656.

COCKERELL, T.D.A. 1919. The metallic-colored halictine bees of the Philippine Islands. Philipp. J. Sci. 15:10-13.

DALY, H.V. 1961. Biological observations on Hemihalictus lustrans, with a description of the larva (Hymenoptera: Halictidae). J. Kansas Entomol. Soc. 34: 134-140.

DANFORTH, B.N. 1999. Phylogeny of the bee genus Lasioglossum (Hymenoptera: Halictidae) based on mitochondrial COI sequence data. Syst. Entomol. 24(4): 377-393.

DANFORTH, B.N. and S. JI. 1998. Elongation factor-1 $\alpha$ occurs as two copies in bees: Implications for phylogenetic analysis of EF-1 $\alpha$ sequences in insects. Mol. Biol. Evol. 15:225-235.

DANFORTH, B.N., H. SAUQUET, and L. PACKER. 1999. Phylogeny of the bee genus Halictus (Hymenoptera: Halictidae) based on parsimony and likelihood analyses of nuclear $\mathrm{EF}-1 \alpha$ sequence data. Mol. Phylogenet. Evol. 13:605-618.

EBMER, A.W. 1987. Die europaischen Arten der Gattungen Halictus Latreille 1804 und Lasioglossum Curtis $1833 \mathrm{mit}$ illustrierten Bestimmungstabellen (Insecta: Hymenoptera: Apoidea: Halictidae: Halictinae) 1. Allgemeiner Teil, Tabelle der Gattungen. Senckenbergiana biologie 68(1/3): 
$59-148$.

EBMER, A.W. 1995. Asiatische Halictidae, 3. Die Artengruppe der Lasioglossum carinate-Evylaeus (Insecta: Hymenoptera: Apoidea: Halictidae: Halictinae). Linz. biol. Beitrag $27(2)$ : 525-652.

EBMER, A.W. 1997. Asiatische Halictidae, 6. Lasioglossum carinaless-Evylaeus: Ergänzungen zu den Artengruppen von $L$. nitidiusculum und $L$. punctatissimum s.l., sowie die Artengruppe des L. marginellum (Insecta: Hymenoptera: Apoidea: Halictidae: Halictinae). Linz. biol. Beitrag 29(2): 921-982

FELSENSTEIN, J. 1985. Confidence limits on phylogenies: an approach using the bootstrap. Evolution 39:783-791.

FRATI, F., C. SIMON, J. SULLIVAN, and D.L. SWOFFORD. 1997. Evolution of the mitochondrial cytochrome oxidase II gene in Collembola. J. Mol. Evol. 44: 145-158.

FRIEDLANDER, T.P., REGIER, J.C. and MITTER, C. 1992. Nuclear gene sequences for higher level phylogenetic analysis: 14 promising candidates. Syst. Biol. 41:483-490.

FRIEDLANDER, T.P., REGIER, J.C. and MITTER, C. 1994. Phylogenetic information content of five nuclear gene sequences in animals: initial assessment of character sets from concordance and divergence studies. Syst. Biol. 43:511-525.

HOUSTON, T.F. 1970. Discovery of an apparent male soldier caste in a nest of a halictine bee (Hymenoptera: Halictidae), with notes on the nest. Aust. J. Zool. 18:345-351. 
HOVEMANN, B., S. RICHTER, U. WALLDORF, and C. CZIEPLUCH. 1988. Two genes encode related cytoplasmic elongation factors $1 \alpha$ $(\mathrm{EF}-1 \alpha)$ in Drosophila melanogaster with continuous and stage specific expression. Nucl. Acids Res. 16:3175-3194.

HUELSENBECK, J.P. and K.A. CRANDALL. 1997. Phylogeny estimation and hypothesis testing using maximum likelihood. Ann. Rev. Ecol. Syst. $28: 437-466$.

KNERER, G., and M. SCHWARZ. 1976. Halictine social evolution: the Australian enigma. Science 194: 445-448.

KNERER, G. , \& M. SCHWARZ. 1978. Beobachtungen an australischen Furchenbienen (Hymenoptera; Halictinae). Zool. Anzeiger 200: 321-333.

KROMBEIN, K.V., P.D. HURD, D.R. SMITH, and B.D. BURKS. 1979 . Catalog of Hymenoptera in America North of Mexico (3 vols.). Smithsonian Institution Press, Washington, DC.

KUKUK, P.F. 1992. Social interactions and familiarity in a communal halictine bee Lasioglossum hemichalceum. Ethology 91: 291-300.

KUKUK, P.F. and R.H. CROZIER. 1990. Trophallaxis in a communal halictine bee Lasioglossum (Chilalictus) erythrurum. Proc. Natl. Acad. Sci., USA 87: 5401-5404.

KUKUK, P.F. and G.K. SAGE. 1994. Reproductivity and relatedness in a communal halictine bee, Lasioglossum (Chilalictus) hemichalceum. Insectes Soc. 41: 443-455.

KUKUK, P.F. and M. SCHWARZ. 1987. Intranest behavior of the 
communal sweat bee Lasioglossum (Chilalictus) erythrurum (Hymenoptera: Halictidae). J. Kansas Entomol. Soc. 60: 58-64 .

KUKUK, P.F. and M. SCHWARZ. 1988. Macrocephalic male bees as functional reproductives and probable guards. Pan-Pacific Entomologist 64: 131-137.

MARONI, G. 1993. An Atlas of Drosophila genes. Oxford University Press, Oxford.

MCCONNELL-GARNER, J. and P.F. KUKUK. 1997. Behavioral interactions of two solitary, halictine bees with comparisons among solitary, communal and eusocial species. Ethology 103: 19-32.

MCGINLEY, R.J. 2000. Studies of Halictinae (Apoidea: Halictidae), II: revision of Sphecodogastra Ashmead, floral specialists on Onagraceae. Smithsonian Contributions to Zoology (in press) .

MICHENER, C.D. 1960. Notes on the biology and supposed parthenogenesis of halictine bees from the Australian region. J. Kansas Entomol. Soc. 33:85-96.

MICHENER, C.D. 1965. A classification of the bees of the Australian and South Pacific regions. Bull. Am. Mus. Nat. Hist. 130:1-362.

MICHENER, C.D. 1974. The Social Behavior of the Bees. Harvard Universiy Press, Cambridge, Massachusetts.

MICHENER, C.D. 1978a. The parasitic groups of Halictidae 
(Hymenoptera, Apoidea). Univ. Kansas Sci. Bull. 51(10):291339.

MICHENER, C.D. 1979a. Biogeography of the bees. Ann. Missouri Bot. Gard. $66: 277-347$.

MICHENER, C.D 1979b. The genus Homalictus in Fiji (Hymenoptera: Halictidae). Pac. Ins. 21(2-3): 227-234.

MICHENER, C.D. 1980a. The large species of Homalictus and related halictines from the New Guinea area (Hymenoptera, Apoidea). Am. Mus. Novit. 2693: 1-21.

MICHENER, C.D. 1980b. A new Philippine Homalictus with unusual wing venation (Hymenoptera: Apoidea). J. Kansas Entomol. Soc. $53(2): 423-426$.

MICHENER, C.D. 1990. Reproduction and castes in social halictine bees. Pages 77-121 in Social Insects: an Evolutionary Approach to Castes and Reproduction (W. Engels, ed.). Springer-Verlag, New York, New York.

MICHENER, C.D. 2000. Bees of the World. Johns Hopkins University Press, Baltimore, Maryland.

MITCHELL, A., CHO, S., REGIER, J.C., MITTER, C., POOLE, R.W. and MATHEWS, M. 1997. Phylogenetic utility of elongation factor$1 \alpha$ in Noctuidea (Insecta: Lepidoptera): the limits of synonymous substitution. Mol. Biol. Evol. 14:381-390.

MOURE, J.C., and P.D. HURD, Jr. 1987. An Annotated Catalog of the Halictid Bees of the Western Hemisphere (Hymenoptera: Halictidae). Smithsonian Institution Press, Washington, DC. 
Danforth \& Ji

PACKER, L. 1993. Multiple foundress associations in sweat bees (Hymenoptera: Halictidae). Pages 214-233 in Queen Number and Sociality in Insects (L. Keller, ed.). Oxford University Press, Oxford.

PACKER, L. 2000. A phylogenetic analysis of western European species of the Lasioglossum leucozonium species group (Hymenoptera: Halictidae): sociobiological and taxonomic implications. Can. J. Zool. (in press).

PALUMBI, S.R. 1996. Nucleic acids II: the polymerase chain reaction. Pages 205-247 in Molecular Systematics, 2nd Ed. (D.M. Hillis, C. Moritz and B.K. Mable, eds.). Sinauer Associates, Sunderland, Massachusetts.

PAULY, A. 1980. Les espéces indonesiennes du genre Homalictus Cockerell (Hymenoptera: Apoidea: Halictinae). Zool. Meded., Leiden $55(2): 11-28$.

PAULY, A. 1986. Les abeilles de la sous-famille des Halictinae en Nouvelle-Guinée et dans l'Archipel Bismark (Hymenoptera: Apoidea: Halictidae). Zool. Verh., Leiden $0(227)$ : 3-58.

PERKINS, R.C. and L.E. CHEESMAN. 1928. Hymenoptera, fasc. 1, Apoidea, Sphecoidea, and Vespoidea. Insects of Samoa, Pt. 5. pp. 1-58.

RAYMENT, T. 1935. A Cluster of Bees. Endeavor Press. Sydney. 752 pp.

RAYMENT, T. 1955. Dimorphism and parthenogenesis in halictine bees. Aust. Zool. 12: 142-153. 
SIBLEY, C.G., and J.E. AHLQUIST. 1985. The phylogeny and classification of the Austro-Papuan passerine birds. Emu 85: $1-14$

SIBLEY, C.G., and J.E. AHLQUIST. 1990. Phylogeny and Classification of Birds: a study in Molecular Evolution. Yale University Press: New Haven. xxiii + 976 pp.

SIBLEY, C.G., J.E. AHLQUIST, and B.L. MONROE, JR. 1988. A classification of the living birds of the world based on DNA-DNA hybridization studies. Auk 105:409-423.

SULLIVAN, J. and B.L. SWOFFORD. 1997. Are guinea pigs rodents? The importance of adequate models in molecular phylogenetics. J. Mammalian Evol. 4:77-86.

SWOFFORD, D.L. 1999. PAUP: Phylogenetic Analysis Using Parsimony, version 4.0b2, Illinois Natural History Survey, Champaign, Illinois.

SWOFFORD, D.L., G.J. OLSEN, P.J. WADDELL, and D.M. HILLIS. 1996. Phylogenentic inference. Pages 407-514 in Molecular Systematics, 2nd Ed. (D.M. Hillis, C. Moritz and B.K. Mable, eds.). Sinauer Associates, Sunderland, Massachusetts.

WALLDORF, U., and B.T. HOVEMANN. 1990. Apis mellifera cytoplasmic elongation factor $1 \alpha(\mathrm{EF}-1 \alpha)$ is closely related to Drosophila melanogaster EF-1 $\alpha$. FEBS 267:245-249.

WALKER, K.L. 1986. Revision of the Australian species of the genus Homalictus Cockerell (Hymenoptera: Halictidae). Mem. Mus. Vict. $47: 105-200$. 
WALKER, K.L. 1993. Pachyhalictus stirlingi (Cockerell)

(Hymenoptera: Halictidae): A unique Australian bee. Australian Entomol. 20(2): 59-65.

WALKER, K.L. 1995. Revision of the Australian native bee subgenus Lasioglossum (Chilalictus) (Hymenoptera: Halictidae). Mem. Mus. Victoria 55(1\& 2): 1-423.

WALKER, K.L. 1996. A new species of Australian Pachyhalictus Cockerell (Hymenoptera: Halictidae). Australian Entomol. $23(4): 125-131$.

WALKER, K.L. 1997. Supplement to a revision of Australian members of the bee genus Homalictus (Cockerell) (Hymenoptera: Halictidae). Mem. Mus. Victoria 56(1): 69-82.

WARD, S.A. and P.F. KUKUK. 1998. Context-dependent behavior and the benefits of communal nesting. Am. Nat. 152(2):249-263.

WCISLO, W.T. 1988. The roles of seasonality, host synchrony, and behavior in the evolutions and distributions of nest parasites in Hymenoptera (Insecta), with special reference to bees (Apoidea). Biol. Rev. 62:515-543.

WCISLO, W.T. 1997. Behavioral environments of sweat bees (Hymenoptera: Halictidae) in relation to variability in social organization. Pages 316-332 in The Evolution of Social Behavior in Insects and Arachnids (B.J. Crespi and J.C. Choe, eds.). Cambridge University Press, Cambridge, Massachusetts.

YANEGA, D. 1997. Demography and sociality in halictine bees (Hymenoptera: Halictidae). Pages 293-315 in The Evolution of 
Danforth \& Ji

Social Behavior in Insects and Arachnids (B.J. Crespi and J.C. Choe, eds.). Cambridge University Press, Cambridge, Massachusetts.

YEATES, D.K. and E.M. EXLEY. 1986. The genus Nomioides Schenck (Hymenoptera: Halictidae) in Australia. J. Australian Entomol. Soc. 25(2):115-121. 
Table 1. Classification of the subgenera of Lasioglossum (modified slightly from Michener, 2000).

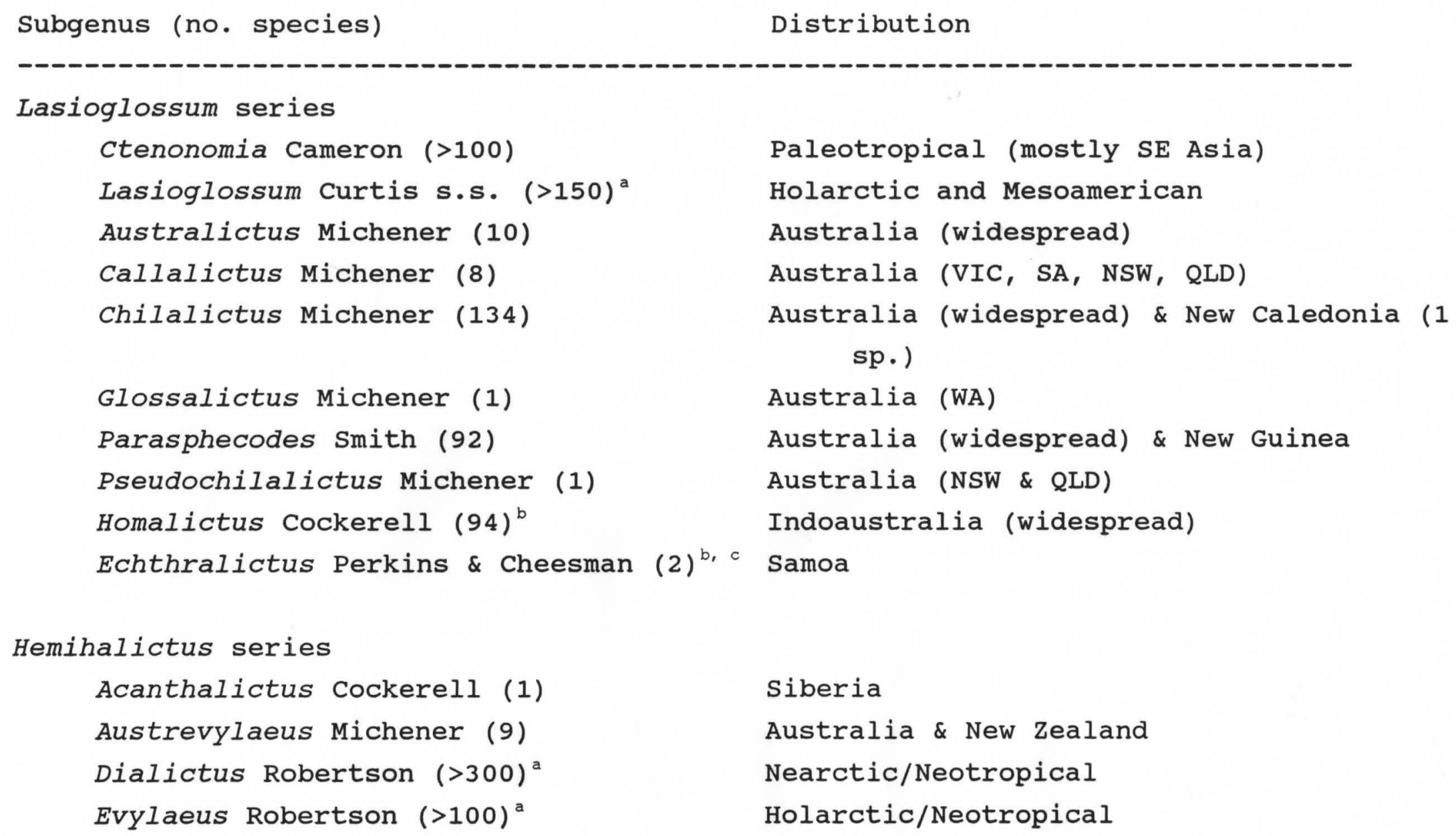


Danforth \& Ji

Hemihalictus Cockerell (1)

Paradialictus Pauly (1)

Paralictus Robertson (3) ${ }^{c}$

Sellalictus Pauly (11)

Sphecodogastra Ashmead (8)

Sudila Cameron (6)
Nearctic

Africa (Zaire)

Nearctic

Africa (Zaire to Cape Prov.)

Nearctic

Sri Lanka and Malaysia

a Indicates subgenera with both solitary and eusocial species.

b Previously not considered as part of Lasioglossum.

c Indicates socially parasitic subgenera. 


\section{Danforth \& Ji}

Table 2 -- Taxa included in this study, collecting localities, specimen voucher codes, and GenBank Accession numbers.

\begin{tabular}{|c|c|c|c|}
\hline Species & Locality & $\begin{array}{l}\text { Voucher } \\
\text { Code }^{a}\end{array}$ & $\begin{array}{l}\text { GenBank } \\
\text { Accession }\end{array}$ \\
\hline \multicolumn{4}{|l|}{ Outgroup taxa: } \\
\hline Augochlora pura (Say) & Ithaca, New York, USA & Aupu333 & AF140314 \\
\hline Augochloropsis metallica (Fabricius) & Ithaca, New York, USA & Aume334 & AF140315 \\
\hline Megalopta genalis Meade-Waldo & $\begin{array}{l}\text { Smithsonian Tropical Res. Station, } \\
\text { Republic of Panamá }\end{array}$ & Mgge247 & AF 140316 \\
\hline Neocorynura discolor (Smith) & Colombia & Nedi249 & AF140317 \\
\hline Agapostemon kohliellus (Vachal) & Dominican Republic & Agko12 & AF140318 \\
\hline Agapostemon sericeus (Forster) & Ithaca, New York, USA & Agse162 & AF140319 \\
\hline Agapostemon tyleri (Cockerell) & Portal, Arizona, USA & Agty230 & AF140320 \\
\hline Agapostemon virescens (Fabricius) & Ithaca, NY, USA & Agvr161 & AF140321 \\
\hline Pseudagapostemon brasiliensis Cure & Minas Gerais, Brazil & Psbr 347 & AF140323 \\
\hline Halictus (Halictus) farinosus Smith & Logan, Utah, USA & Hafa25 & AF140332 \\
\hline Halictus (Halictus) ligatus Say & Rock Hill, South Carolina, USA & $\operatorname{Hali}(\mathrm{c})$ & AF140300 \\
\hline Halictus (Halictus) poeyi Lepeletier & Rock Hill, South Carolina, USA & Hapo (d) & AF140303 \\
\hline Halictus (Halictus) rubicundus (Christ) & Missoula, Montana, USA & Haru32 & AF140335 \\
\hline Halictus (Seladonia) confusus Smith & Junius Ponds, New York, USA & Haco301 & AF140304 \\
\hline Mexalictus arizonensis Eickwort & Miller canyon, Arizona, USA & Mxaz97 & AF140322 \\
\hline Sphecodes minor Robertson & Sydney, Nova Scotia, Canada & Spmi21 & AF140324 \\
\hline Sphecodes ranunculi Robertson & Ithaca, New York, USA & Spra337 & AF 140325 \\
\hline \multicolumn{4}{|l|}{ Ingroup taxa: } \\
\hline L. (Chilalictus) convexum (Smith) & Cobboboonee S.F., Victoria, Australia & Chcv156 & AF264790 \\
\hline
\end{tabular}


L. (Chilalictus) conspicuum (Smith)

L. (Chilalictus) cognatum (Smith)

L. (Chilalictus) erythrurum (Cockerell)

L. (Chilalictus) florale (Smith)

L. (Chilalictus) lanarium (Smith)

L. (Chilalictus) mediopolitum (Ckll.)

L. (Chilalictus) mirandum (Cockerell)

L. (Chilalictus) parasphecodum (Walker)

L. (Chilalictus) supralucens (Cockerell)
Cobboboonee S.F., Victoria, Australia Cobboboonee S.F., Victoria, Australia $6 \mathrm{~km}$ E. SA/WA border, S. Australia $6 \mathrm{~km} \mathrm{E.} \mathrm{SA/WA} \mathrm{border,} \mathrm{S.} \mathrm{Australia}$ Cobboboonee S.F., Victoria, Australia $6 \mathrm{~km}$ E. SA/WA border, S. Australia Bluff Knoll, Stirling Range NP, W. Australia, Australia $6 \mathrm{~km}$ E. SA/WA border, S. Australia Bluff Knoll, stirling Range NP, W. Australia, Australia

Ontario, Canada Republic of Panamá Puerto Rico

Mt. Lemmon, Arizona, USA Ithaca, New York, USA Puerto Rico Junius Ponds, New York, USA Junius Ponds, New York, USA Junius Ponds, New York, USA Republic of Panamá Junius Ponds, New York, USA Junius Ponds, New York, USA

Les Eyzies, Dordogne, France (social) Longemer \& Col de la Schlucht, Vosges, France (solitary)

\section{Chcs 155 \\ AF264789 \\ Chcg 317 AF264788 \\ Chey 308 \\ Chf 1320 \\ Chla316 \\ Chmd291 \\ Chmi319}

Chps 318

Chsu295

AF2 6496

AF26497

Dicr 66

Difi341

Digu48

Diha277

Diim27

Dipa 7

Dipi71

Dirh79

Ditg81

Dium 322

Divi67

Dizp74

Eval99

Eval104
AF264801

AF2 64802

AF264803

AF264804

AF264805

AF264806

AF 264807

AF264808

AF 264809

AF2 64810

AF2 64811

AF2 64812

AF2 64814

AF264813 


\section{Danforth \& Ji}

L. (Evylaeus) apristum (Vachal)

L. (Evylaeus) boreale Svensson

L. (Evylaeus) calceatum (Scopoli)

L. (Evylaeus) cinctipes (Provancher)

L. (Evylaeus) Comagenense Knerer \& Atwood

L. (Evylaeus) duplex (Dalla Torre)

L. (Evylaeus) fulvicorne (Kirby)

L. (Evylaeus) gattaca Danforth \& Wcislo

L. (Evylaeus) laticeps (Schenck)

L. (Evylaeus) lineare (Schenck)

L. (Evylaeus) marginatum (Brullé)

L. (Evylaeus) malachurum (Kirby)

L. (Evylaeus) mediterraneum (Blûthgen)

L. (Evylaeus) morio (Fabricius)

L. (Evylaeus) nigripes (Lepeletier)

L. (Evylaeus) pauxillum (Schenck)

L. (Evylaeus) pectorale (Smith)

L. (Evylaeus) politum (Schenck)

L. (Evylaeus) puncticolle (Morawitz)

L. (Evylaeus) quebecense (Crawford)

L. (Evylaeus) subtropicum Sakagami

L. (Evylaeus) truncatum (Robertson)

L. (Evylaeus) villosulum (Kirby)

L. (Hemihalictus) lustrans (Cockerell)
Mt.Sanbe, Shimane Prefecture, Japan

Inuvik, NWT, Canada

Les Eyzies, Dordogne, France

Ithaca, New York, USA

Sydney, Nova Scotia, Canada

Sendai, Miyagi Prefecture, Japan

Ventoux, Vaucluse, France

Chiriquí Province, Republic of Panamá

Les Eyzies, Dordogne, France

Pont-Saint-Vincent, Meurthe et Moselle, France

Les Eyzies, Dordogne, France

Les Eyzies, Dordogne, France

Les Eyzies, Dordogne, France

Les Eyzies, Dordogne, France

Beaumont du Ventoux, Vaucluse, France

Vienna, Austria

Florida, USA

Les Eyzies, Dordogne, France

Les Eyzies, Dordogne, France

no locality data

Iriomote Is., Okinawa Prefecture, Japan

Ithaca, New York, USA

Les Eyzies, Dordogne, France

Bastrop, Texas, USA
Evap145

Evbo262

Evcal05

Evci311

Evco 255

Evdu142

Evfu 310

Evsp324

Evla117

Evli137

Evmg108

Evml111

Evme289

Evmo148

Evng129

Evpa131

Evpe10

Evpo122

Evpu128

Evqu325

Evsu139

Evtr312

Evvil25

Helu186
AF264815

AF2 64816

AF2 64817

AF2 64818

AF2 64819

AF2 64820

AF264821

AF264834

AF2 64822

AF 264823

AF264825

AF2 64826

AF2 64824

AF 264827

AF2 64828

AF2 64829

AF2 64830

AF2 64831

AF2 64832

AF264833

AF264835

AF2 64836

AF 264837

AF2 64838 
L. (Homalictus) megastigmus (Cockerell)

L. (Homalictus) punctatus (Smith)

L. (Lasioglossum) albocinctum Lucas

L. (Lasioglossum) callizonium (Pérez)

L. (Lasioglossum) coriaceum (Smith)

L. (Lasioglossum) desertum (Smith)

L. (Lasioglossum) discum (Smith)

L. (Lasioglossum) fuscipenne (Smith)

L. (Lasioglossum) laevigatum (Kirby)

L. (Lasioglossum) lativentre (Schenck)

L. (Lasioglossum) leucozonium (Schrank)

L. (Lasioglossum) leucozonium (Schrank)

L. (Lasioglossum) majus (Nylander)

L. (Lasioglossum) pavonotum (Cockerell)

L. (Lasioglossum) sexnotatum (Kirby)

L. (Lasioglossum) sisymbrii (Cockerell)

L. (Lasioglossum) titusi (Crawford)

L. (Lasioglossum) zonulum (Smith)

L. (Paralictus) asteris Mitchell

L. (Parasphecodes) hybodinum (Cockl.)

L. (Parasphecodes) olgae (Rayment)

L. (Parasphecodes) olgae (Rayment)
Bluff Knoll, Stirling Range NP,

Homg 360

AF264839

W. Australia, Australia

Adelaide, S. Australia, Australia

Hopu 245

AF264840

\section{France}

Berja, Almeria Prov., Spain

no locality data

Rose Canyon Lake, Arizona, USA

France

Michigan, USA

Les Eyzies, Dordogne, France

Les Eyzies, Dordogne, France

Les Eyzies, Dordogne, France

Ithaca vicinity, New York, USA

France

Point Reyes Natl. Sea Shore, California, USA

Morigny-Champigny, Essonne, France

Chiricahua Mts., Arizona, USA

Twentynine Palms, California, USA

Ithaca, New York, USA

Ithaca, New York, USA

$6 \mathrm{~km} \mathrm{E.} \mathrm{SA} /$ WA border, S. Australia,

$$
\text { Australia }
$$

Cobboboonee S.F., Victoria, Australia

S. Australia, Australia

\begin{tabular}{|c|c|}
\hline Laab315 & AF 338386 \\
\hline Laca 380 & AF26484 \\
\hline Laco15 & AF 264842 \\
\hline Lade 251 & $\mathrm{AF} 264843$ \\
\hline Ladi313 & AF 26485 \\
\hline Lafu 65 & AF 26484 \\
\hline Lala23 & AF 26484 \\
\hline Lalt 120 & AF 26484 \\
\hline Lale133 & AF 26484 \\
\hline Lale170 & AF2 6484 \\
\hline Lamj 314 & AF 26484 \\
\hline Lapa339 & AF 26485 \\
\hline Lasx136 & AF 26485 \\
\hline Lasi253 & AF2 6485 \\
\hline Lati 167 & AF 26485 \\
\hline Lazo284 & AF2 6485 \\
\hline Paas30 & AF 26485 \\
\hline Pahy299 & AF 26485 \\
\hline Ctsp153 & AF 26479 \\
\hline Ctsp397 & AF 2648 \\
\hline
\end{tabular}


Danforth \& Ji

L. (Parasphecodes) sp.

Cobboboonee S.F., Victoria, Australia Pasp160

AF264858

L. (Sphecodogastra) noctivagum Linsley

Monahans Sand Hills, Texas, USA

AF264859

\& MacSwain

L. (Sphecodogastra) oenotherae

Ithaca, New York, USA

Stoe 54

AF264860 (Stevens)

L. (Sudila) alphenum (Cameron)

Hakgala Botanical Garden, NE

District, Sri Lanka

Sual390 AF264861

Cobboboonee S.F., Victoria, Australia

Ctsp297

AF264799

L. (Subgen. Nov. N.) NDA(1)-A

a Voucher specimens and DNA extractions are housed in the Cornell University Insect collection. 
Danforth \& Ji

Table 3 -- Base composition of $\mathrm{EF}-1 \alpha$ sequence data.

\begin{tabular}{|c|c|c|c|c|c|}
\hline & A & C & G & $\mathrm{T}$ & $p$-value \\
\hline Exon & 26.5 & 24.7 & 24.2 & 24.5 & 1.0 \\
\hline nt 1 & 28.7 & 18.2 & 38.3 & 14.8 & 1.0 \\
\hline$n+2$ & 30.2 & 26.1 & 16.2 & 27.5 & 1.0 \\
\hline nt3 & 20.7 & 29.8 & 18.1 & 31.3 & 1.0 \\
\hline Intron & 29.5 & 16.0 & 19.0 & 35.5 & 1.0 \\
\hline Overall & 27.4 & 22.2 & 22.7 & 27.6 & 1.0 \\
\hline
\end{tabular}

a p-values refer to the probability of rejecting the null hypothesis of homogeneity among taxa in base composition. 
Table 4 -- Composition of introns and exons.

\begin{tabular}{|c|c|c|c|c|}
\hline & Total & Const. & $\begin{array}{l}\text { Pars. } \\
\text { Uninf. }\end{array}$ & $\begin{array}{l}\text { Pars. } \\
\text { Inf. }\end{array}$ \\
\hline Exons & 1074 & 731 & 63 & 280 \\
\hline nt1 & 358 & 318 & 14 & 26 \\
\hline nt2 & 358 & 335 & 11 & 12 \\
\hline nt3 & 358 & 78 & 38 & 242 \\
\hline Introns $^{a}$ & 489 & 168 & 60 & 261 \\
\hline Amino acids & 358 & 314 & 19 & 25 \\
\hline
\end{tabular}

a Based on gap coded data set. 
Figure captions

Fig. 1. Strict consensus tree based on analysis of unweighted nucleotide data; exons plus introns with indel mutations coded as described in Danforth et. al. (1999) (1540 nucleotide positions; 534 parsimony informative characters; $\mathrm{ci}=0.3946, \mathrm{ri}=0.7541$, length $=2477$ ). Outgroups included Halictus (Seladonia) confusus, Halictus (Halictus) farinosus, H. (H.) rubicundus, H. (H.) ligatus, H. (H.) poeyi, Agapostemon kohliellus, A. sericeus, $A$. tyleri, A. virescens, Pseudagapostemon brasilensis, Mexalictus arizonensis, sphecodes minor, sphecodes ranunculi, Augochloropsis metallica, Megalopta genalis, Augochlora pura, and Neocorynura discolor.

Fig. 2. $50 \%$ bootstrap consensus tree based on analysis of unweighted nucleotide data; exons plus introns with indel mutations coded as described in Danforth et. al. (1999). outgroups as in Fig. 1 .

Fig. 3. - Ln likelihoods based on the equal weights parsimony trees for 20 models of sequence evolution. Likelihoods improved slightly with branch swapping, as described in Results. SSR refers to site-specific rates for introns, first, second, and third positions. The arrow indicates the model used for tree searching.

Fig. 4. -- Maximum likelihood analysis based on the K2P+SSR model. -Ln likelihood $=15361.75$. Branch lengths are shown as proportional to character changes. 


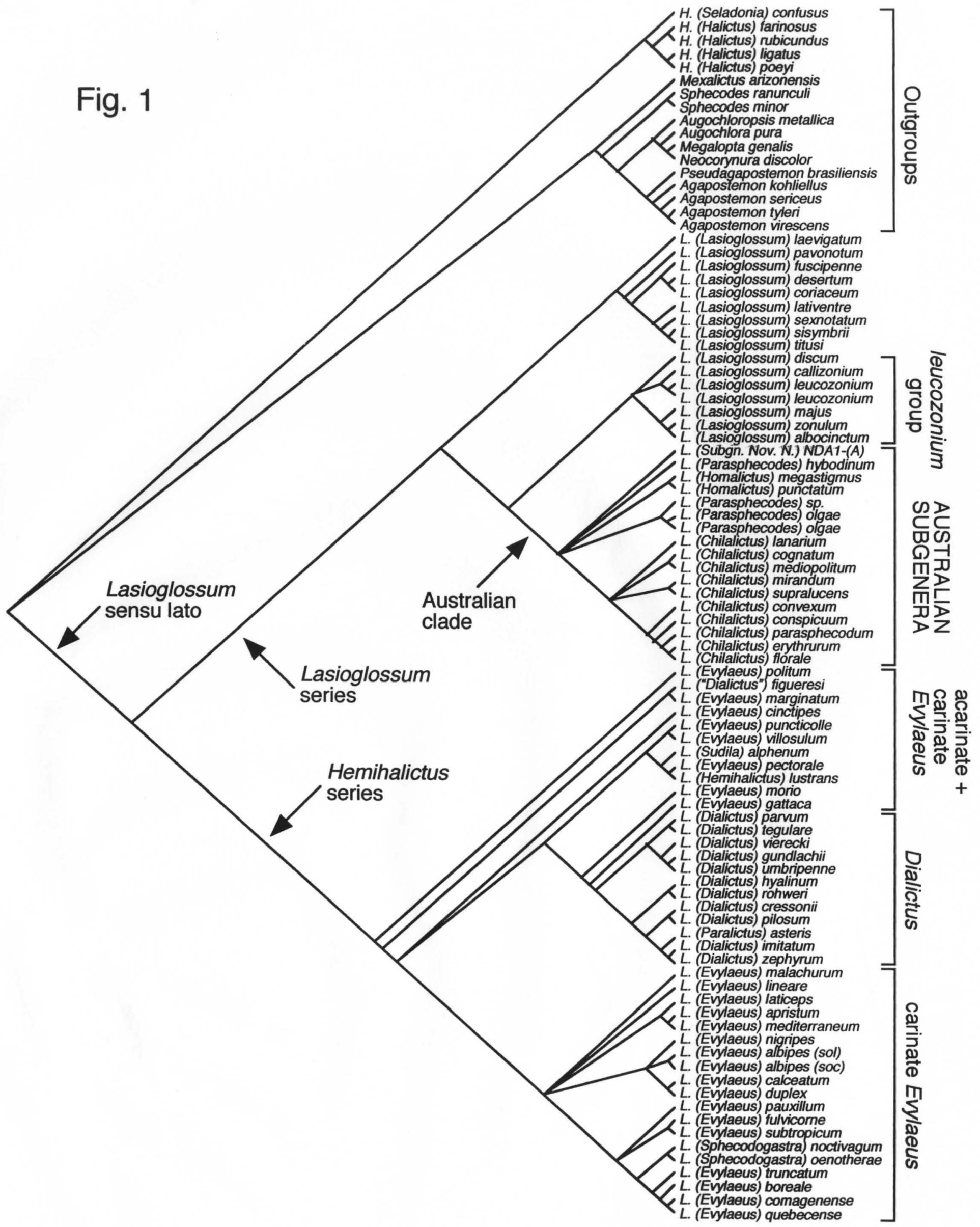




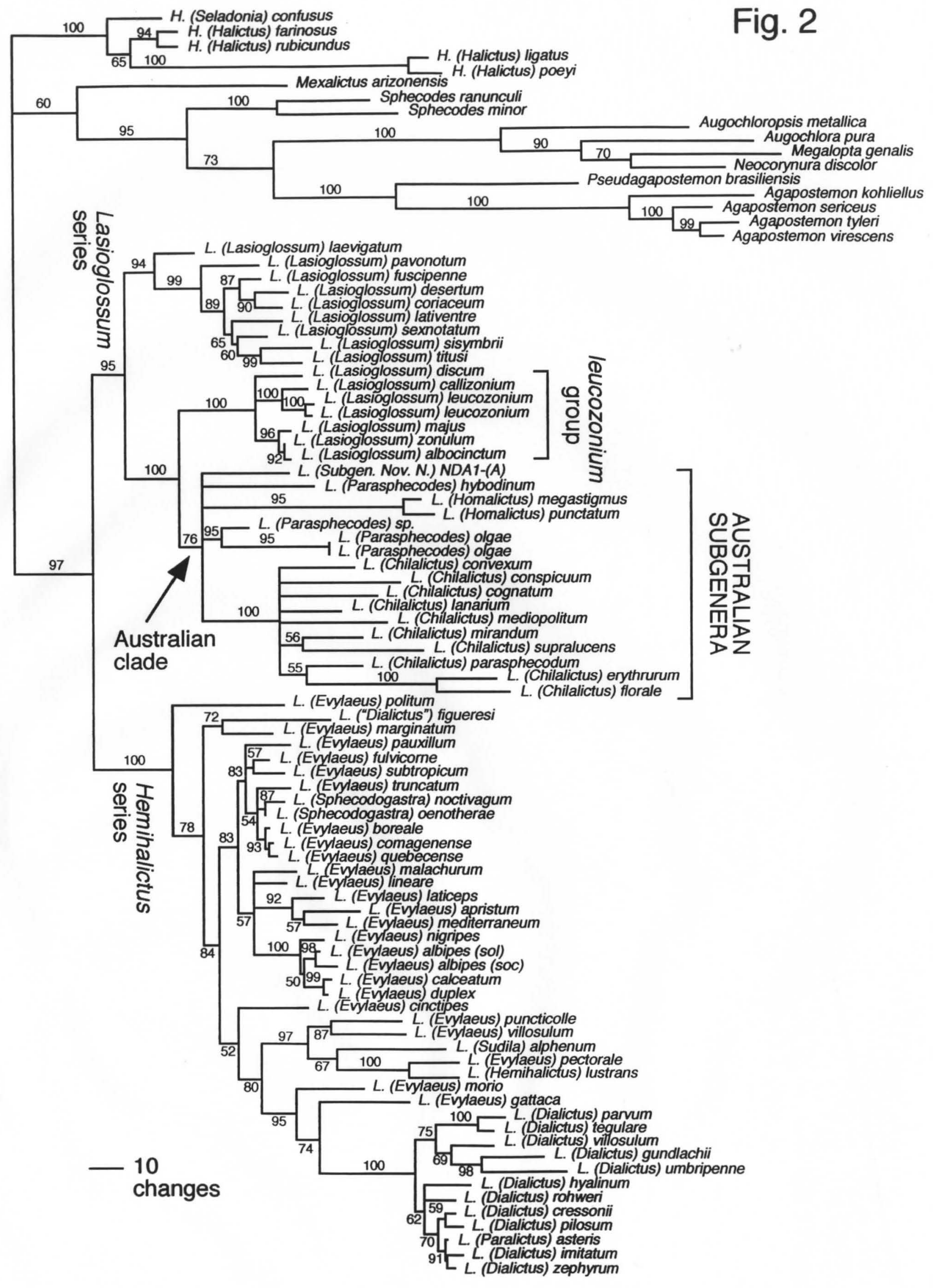




\section{-Ln likelihood}
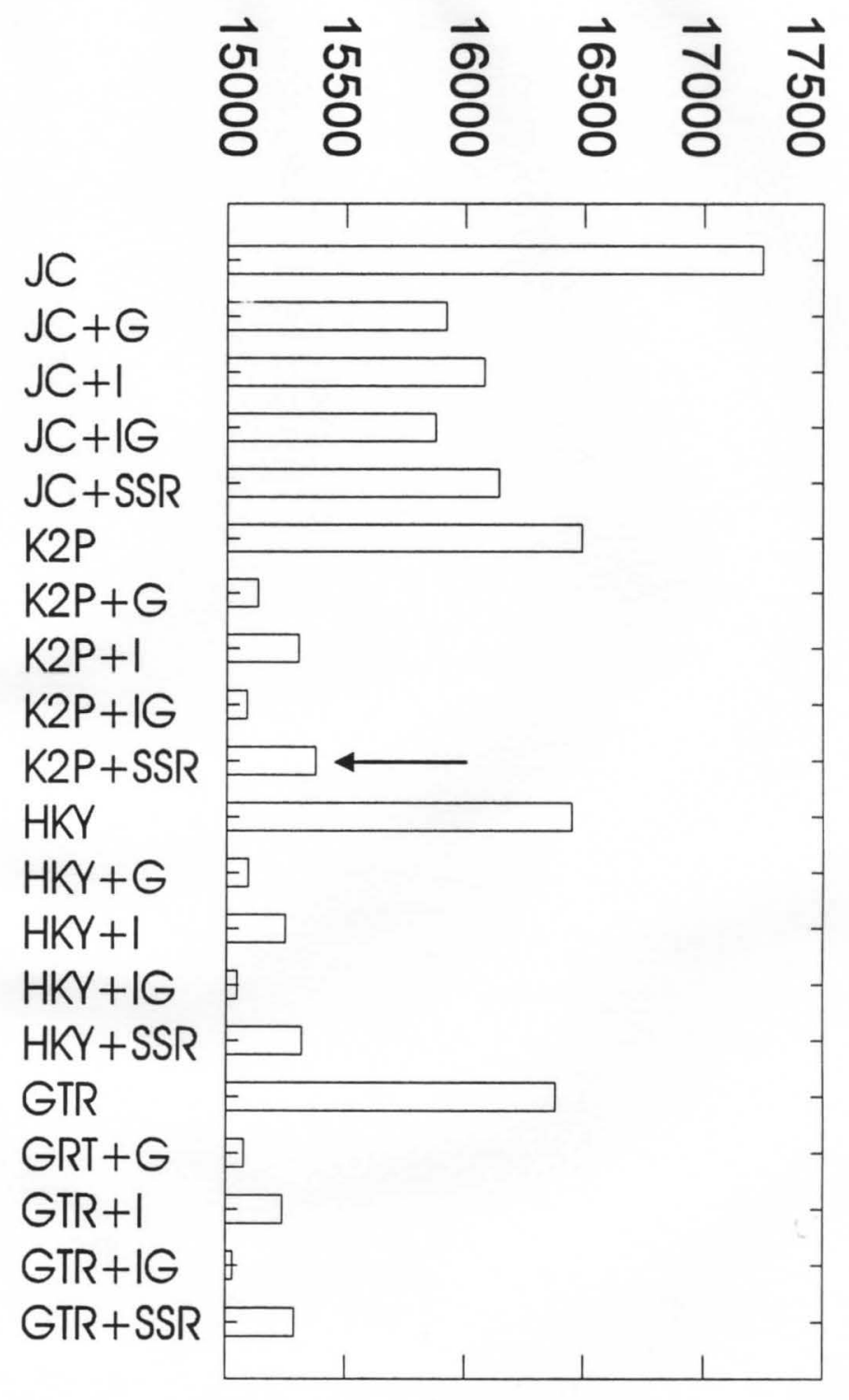
Fig. 4

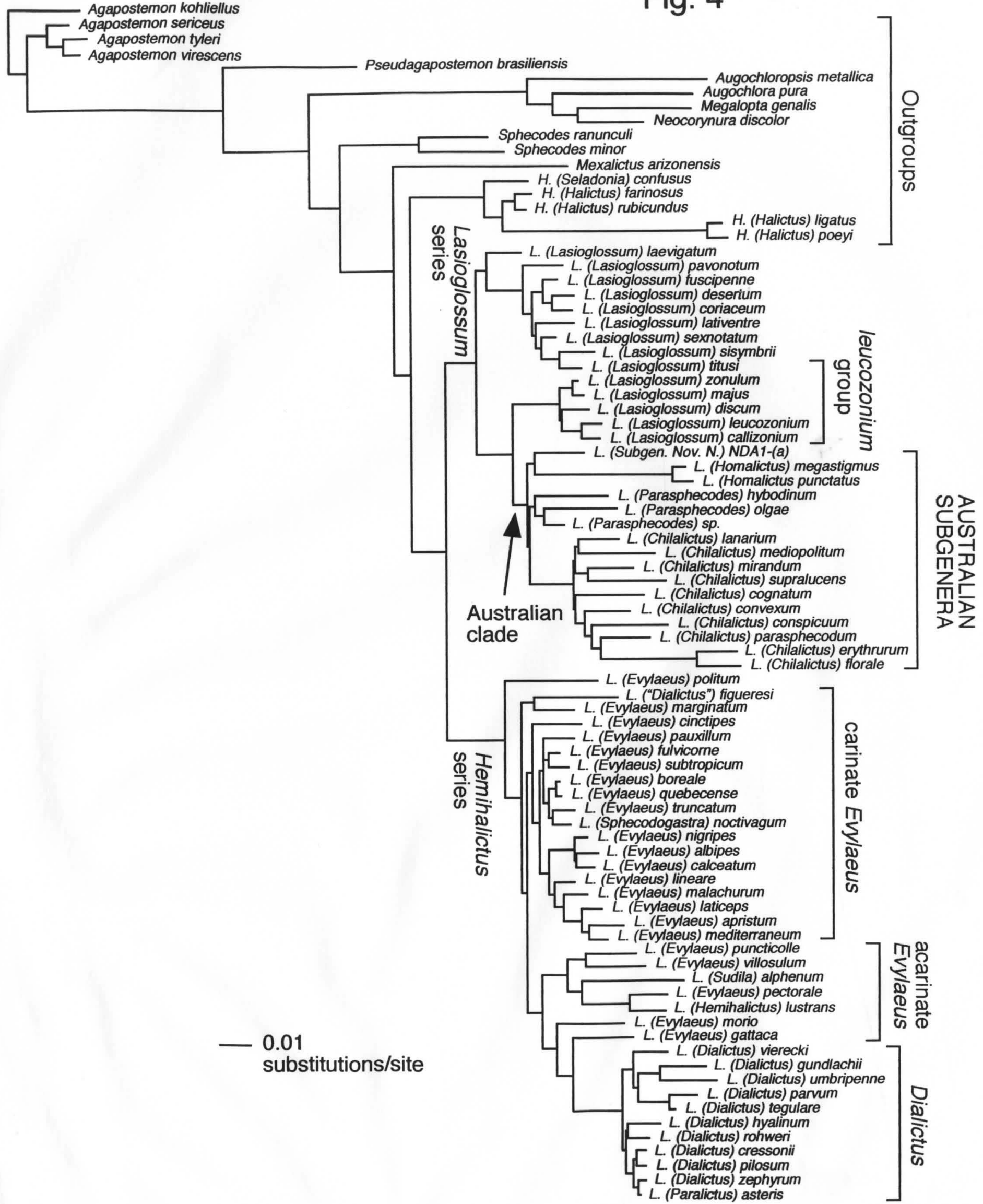

